\title{
ERP system implementation: benefits and economic effectiveness
}

\author{
Andrejs Tambovcevs \\ Faculty of Computer Science and Information Technology \\ Riga Technical University \\ Riga, Latvia \\ ata2000@inbox.lv
}

\author{
Tatjana Tambovceva \\ Faculty of Engineering Economics and Management \\ Riga Technical University \\ Riga, Latvia \\ tatjana.tambovceva@rtu.lv
}

Received: March 21, 2021. Revised: November 22, 2021. Accepted: December 19, 2021. Published: January 5, 2022.

\begin{abstract}
The enterprise information system offers the service platform to improve the efficiency of enterprise work. Information systems are widely used in different areas and improve the efficiency of enterprise activities. The main purpose of this paper is to present the ERP systems implementation challenges together with identifying the benefits from the implementation and economic effectiveness of ERP systems.
\end{abstract}

Keywords-Enterprise Resource Planning (ERP), ERP system, ERP implementation, Enterprise Information Systems

\section{INTRODUCTION}

The development in global information technologies and the competitive market climate have pushed many companies to transform their businesses. An information system (IS) is a group of components which can increase the competitiveness and gain better information for decision making. Consequently, many organizations decide to implement IS in order to improve the effectiveness and efficiency of their organizations. However, a lack of awareness of numerous and varied challenging issues surrounding the implementation process could be problematic for the whole process. Furthermore, the problem of a lack of key success issues seems to be a serious obstacle for the information system implementation process. Additionally, IS implementation has effects on an organization and these effects are related to the consequences of the business processes. Consequently, this issue is critical and crucial for an organization to consider when they implement a new IS.

Implementation of IS makes significant changes to the management of business processes. The issue of assessing the effectiveness of implementation of IS is a very important issue, as any major costs would require support, especially from the leaders of the organization.

The main purpose of this paper is to present the ERP systems implementation challenges together with identifying the benefits from the implementation and economic effectiveness of ERP systems.

\section{A. Enterprise information systems}

Information systems (IS) are combinations of hardware, software, and telecommunications networks which people build and use to collect, create, and distribute useful data, typically in organizational settings [12]. Computers are the core component of information systems. Over the past decade, the advent of powerful, relatively inexpensive, easy-to-use computers has had a major impact on business. When we use the term ,information system”, we are talking about computerbased-information systems.

Companies use IS to support their various business processes and activities for internal operations such as manufacturing, order processing, and human resource management. Companies can also use IS to support external interactions with customers, suppliers, and business partners.

Enterprise information systems (EIS) are complex application software packages that contain mechanisms supporting the management of the whole enterprise and integrate all areas of its functioning. They promise the seamless integration of all the information flowing through a company-financial and accounting information, human resource information, supply chain information, and customer information [7].

EIS evolved from material requirements planning (MRP) and manufacturing resource planning (MRP II) systems. Therefore, they started as the support for a variety of transaction-based back-office functions and were then called Enterprise Resource Planning (ERP) systems [29]. However, they further evolved to include support for front-office and inter-organizational activities including supply chain management, customer resource management, and sales force automation [8]; [18]. They started to offer solutions in an attempt to seamlessly link front-office (e.g., sales, marketing, customer services) and back-office (e.g., operations, logistics, financials, human resources) applications to enhance competitive advantages [5].

Because companies within certain industries operate their businesses differently, it is necessary to understand how it can use IS to support its unique internal business activities. Generally, the flow of information through a set of business activities is referred to as a value chain [23], in which information flows through functional areas that facilitate the internal activities of the business (shown in Figure 1). Functional areas can be broken down into primary and support activities. Primary activities are functional areas within an organization that process inputs and produce outputs. Support 
activities are those activities that enable primary activities to

take place.

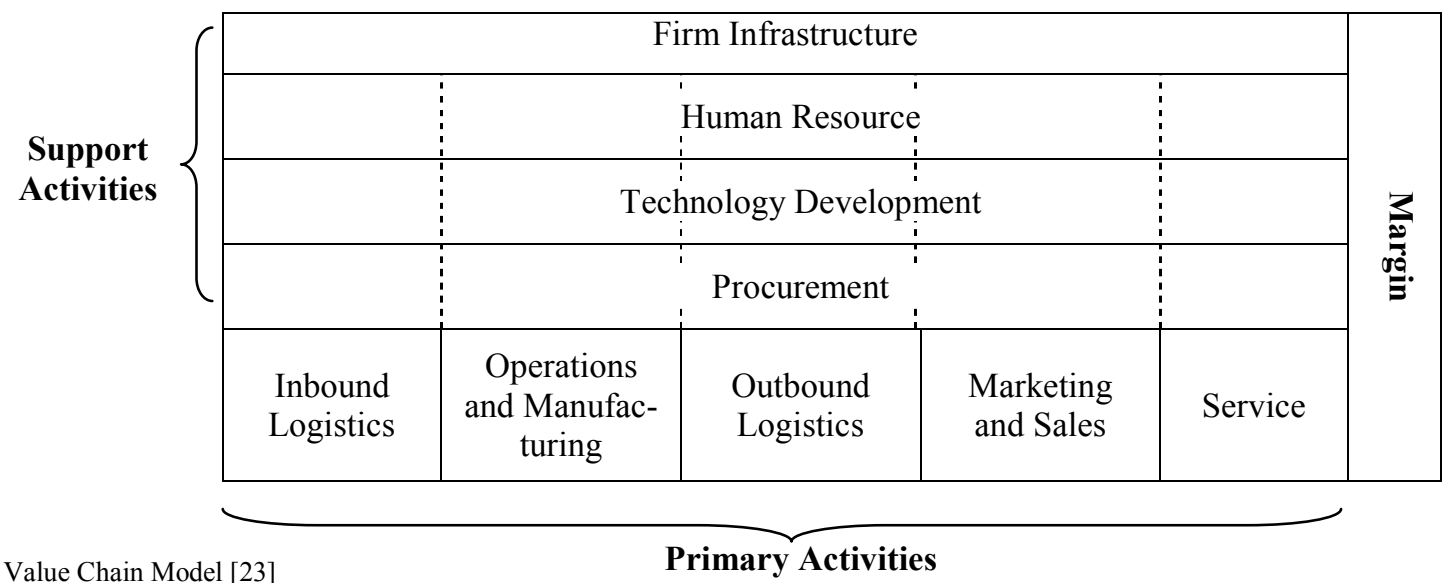

Fig. 1. Porter's Value Chain Model [23]

Primary Activities

Logistics is the management of the flow of goods, information and other resources, including energy and people, between the point of origin and the point of consumption in order to meet the requirements of consumers. Logistics involves the integration of information, transportation, inventory, warehousing, material-handling, and packaging, and occasionally security. Inbound logistics is the management of transport and storage for raw materials received by a business. Outbound logistics is the management of storing, transporting, and distributing for finished goods to its customers.

IS are used to support various resource planning and control processes as well as to provide managers with up-todate information. IS have greatly changed the operations management profession. In the past, orders for supplies had to be places over the phone production processes had to be optimized using tedious calculations, and forecasts were sometimes only educated guesses. Today, Enterprise Resource Planning (ERP) and Supply Chain Management (SCM) systems have eliminated much of the „busy work" associated with making production forecast and placing orders. IS have changed the way organizations promote and sell their products. For example, business-to-customer electronic commerce, enabled by the Internet, allows companies to directly interact with their customers without the need intermediaries.

Additionally, with the use of corporate extranets, companies are connecting to their suppliers' and distributors' networks, helping to reduce costs in procurement and distribution processes. The use of IS has become one of the primary ways that organizations improve their value chains. In Figure 2 is shown a sample value chain and some ways that use of IS can improve productivity within it. 


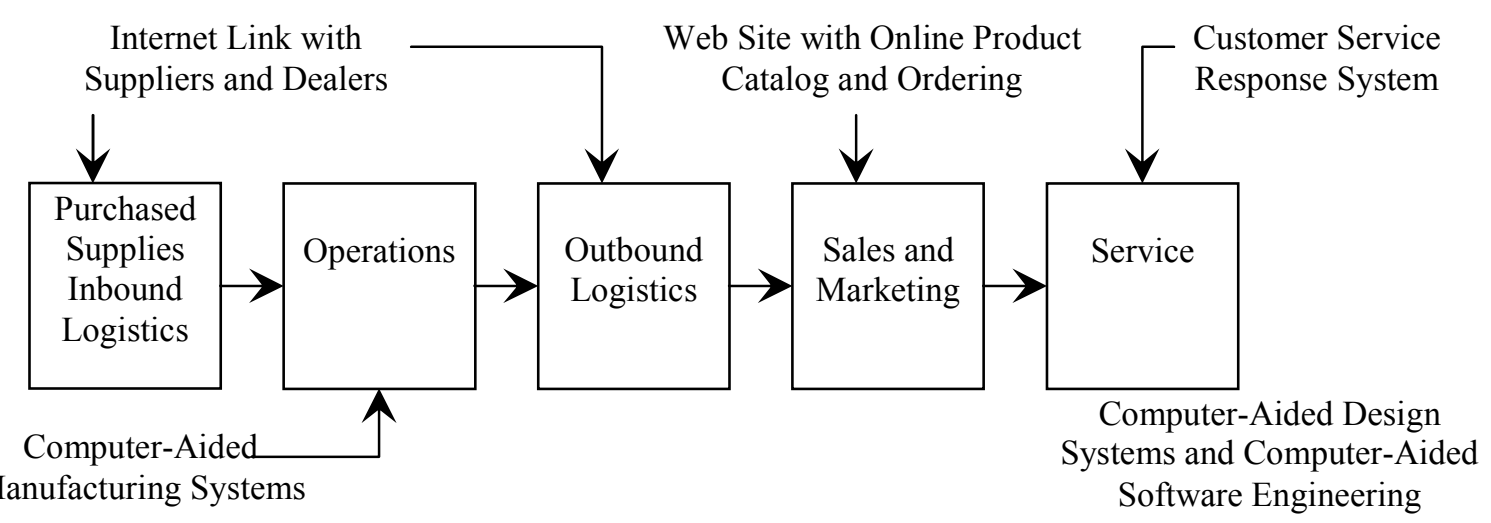

\begin{tabular}{c|cc|}
\cline { 2 - 3 } & & \\
\multirow{2}{*}{$\begin{array}{c}* \\
\text { Project Management } \\
\text { Software Package }\end{array}$} & Product R\&D, Technology, and Systems Development \\
\cline { 2 - 3 } $\begin{array}{c}\text { Financial Decision } \\
\text { Support System }\end{array}$ & Human Resources Management \\
\cline { 2 - 3 }
\end{tabular}

Fig. 2. Sample value chain and corresponding sample uses of information systems to add value [12]

\section{B. Enterprise resource planning systems}

ERP is a complex multimodal software application which tries to integrates all the processes of the company, having as a purpose its perfection and growth in efficiency [1]. From a functional point of view, an ERP integrates all enterprise function (production and R\&D, financial, human resources, marketing), and management function (prevision and planning, organizing, decision, coordination and control).

ERP system focused on the integration of all organization departments, functions and processes within a single computer informational system, capable of supporting all these areas, with their individual and specific requirements. Each department has its own computer informational sub-system, optimized according to the specific characteristics of the development activity, but the ERP system combines all the characteristics within an integrated software program that runs on a unique database so that all the organizations can better share the information and thus better communicate the information. Moreover, the current versions of ERP systems spread over the limits of organization [10].

ERP systems implementation process is well documented. Enterprises recently tend to implement their new enterprise information systems like ERP system in order to gain their competitive advantages and bring up their business efficiency, but the efficiency gained from this new implementation is not quite clear and is difficult to be identified. The most of studies focus mainly on ERP implementation and how to increase the success rate of implementing ERP systems. ERP implementation concept was described by [5]; [6]; [7], [8]; [12]; [14]; [16]. ERP implementation model or methodology was investigated by [2]; [11]; [18]; [20]; [24]; [26]. The importance of considering ERP success at multiple points in time was determined by [1] and [14].

Unfortunately, a lot of organizations didn't gain the intended success by implementing the ERP system because they used the software without operating the necessary organizational changes. In order to make these systems generate the intended effects, their implementation requires, sometime, radical changes. Specialists claim the fact that an efficient exploitation and the benefits of the informational technology can be reached only if the organizations apply the Business Process Reengineering- BPR, in conformity with their current and future perspectives, before implementing any informational ERP system as well as other systems.

ERP allows a firm's functional units to communicate directly with each other. The resulting information network enables four important outcomes [10]:

1. ERP provides a comprehensive information picture that integrates functions, departments, and hierarchical levels into a composite, action-response chain of events. Thus, entering a new order automatically deducts available material from inventory, orders needed material from suppliers, updates the production forecast, revises work schedules, and prepares new market projections.

2. ERP provides a single, comprehensive database in which all business transactions are entered, recorded, processed, monitored, and reported. This reduces data entry and monitoring, facilitates the use of tacit knowledge (intangible, embedded in individual experience), and enables the coordination of customerdriven strategies (such as mass customization).

3. ERP increases the speed of information transactions.

4. ERP increases structural connectivity across units and activities. Transaction consequences become visible and the effects of choices made in one unit become apparent throughout the firm. Structural connectivity makes feasible the use of comprehensive performance tools such as the balanced scorecard. 
Through these benefits, ERP offers the potential for seamless functional integration, enhanced leverage of tangible and intangible resources, efficient and flexible supply-chain management, make-to-order manufacturing, and other value creating possibilities.

ERP systems can be categorizes by price (license fee, and implementation expenses). Usually, big businesses need big ERP applications. Big ERP systems are SAP, Oracle, PeopleSoft and JD Edwards and other (for more then 250,000\$). Medium size businesses go for medium size ERP. The midrange ERP applications include QAD, Microsoft's Navision, Scala etc. (from 50,000\$ to 250,000\$). Small business owners usually think ERP is for someone else, someone bigger. Small, shoestring ERP applications are available for even the smallest enterprise. Smaller systems include popular low cost business applications that are complete but simplified systems (over $50,000 \$)$.

ERP systems are becoming more necessary for almost every firm to improve the competitiveness. According to the success of the implementation of ERP system; companies can obtain a competitive advantage in the global market rapidly. A growing number of companies are investing in ERP systems. Many ERP projects have resulted in substantial tangible and intangible improvements in a variety of areas for the organizations [8]; [28] etc. However, there are a number of examples where organizations were not successful in reaping the potential benefits that motivated them to make large investments in ERP implementations [3]; [5]; [8]; [9]; [28]. ERP projects have an abnormal number of problems, particularly related to cost, customization, and integration with existing systems as evidenced by the large number of failed projects, especially in organizations that are structurally complex and geographically dispersed [18]. Implementations of ERP systems are one of the most difficult investment projects because of the complexity, high cost and adaptation risks. Unfortunately, a lot of organizations didn't gain the intended success by implementing the ERP system because they used the software without operating the necessary organizational changes. In order to make these systems generate the intended effects, their implementation requires, sometime, radical changes.

If ERP only streamlines tasks, manages data, and changes the procedures people use to do their work, it is unlikely to provide long-term competitive benefits. To promote a sustained competitive advantage, firms must be able to use ERP in distinctive ways or in ways that enable the firm to accomplish distinctive outcomes. Sustained competitive benefits only emerge from a firm's ability to create new organizational capabilities that set the firm apart from its rivals, and from the ability to change people's behaviour as learning takes place. Not only must the information that results from ERP implementation be actionable, it must lead to actions that distinguish a firm from its rivals to provide a competitive edge.

The key driving force to implement ERP systems is the need of integrating processes and systems across the global supply chain operation and improving performance and cutting costs [8]; [27].

\section{The benefits of ERP system}

In any discussion on implementing an ERP system, the question "What are the benefits of an ERP System?" appears early in most selection cycles. Through the use of the system the enterprise obtained the following results:

- Enhanced company operation through streamlining, improving and controlling business processes of major importance such as procurement, customer offers, customer complaints, equipment maintenance, marketing campaigns and others.

- Significant cost-reductions and time-savings in all the above mentioned business processes.

- Ability to manage service related personnel and related costs through the use of the resource management module of the system. In the past, the company could allocate only the productive resources' (workers and construction site related costs) cost to each company activity. Now by taking advantage of the resource management (timesheets) module of the system, the enterprise is able to manage the cost of the service personnel (engineering, R\&D departments, etc.) involved.

- Upgraded use of the company's already operating quality management system, which was not supported by an information system. The use of the proposed ERP system enabled the enterprise to avoid much paperwork, to reduce personnel's occupation times with quality management issues and to provide report insight to the management.

- Flexible and efficient production planning by implementing the manufacturing management (scheduling) module of the system. Project delivery times and idle times were reduced significantly, productivity was raised, more precise delivery time assessment incurred stock level minimization and customer satisfaction improved.

- Facilitated communication and data transfer of critical information for the whole enterprise. Now employees have instant access to real-time data, documents and reports that concern their duties. View of information flow is fully customized according to each user position.

- Finally, the company exploited the abilities to control sales and promotion activities through the system, received quantitative data about the results of each promotion technique and managed to increase sales department efficiency.

Here are some areas to look for possible ROI and cost saving:

- Reduce inventory through better visibility and efficiency

- Savings through the reduction in duplicated efforts

- More efficient operations allowing for increase in ability to process transactions (added capacity) 
- Reduction in non-value added activities (lean processing)

- Higher utilization of employees (less transactional, more analytical)

- Improvement in decision making through more accurate and real-time data

A successfully implemented ERP can link all areas of an enterprise including customer relation, manufacturing, human resource, financial management and distribution with customers and suppliers, and forming a highly integrated system with shared data [19]. Potential benefits include drastic declines in inventory, reduction in working capital, abundant information about what customer wants and needs, along with the ability to view and manage the extended enterprise of customers, suppliers, and alliances as an integrated whole.

\section{Economic-effectiveness of ERP system}

Economic effectiveness of ERP system differs in content from the efficiency of the new computer technology and automated management tools. Difficulties in determining the effectiveness of ERP system due to the fact that you need to

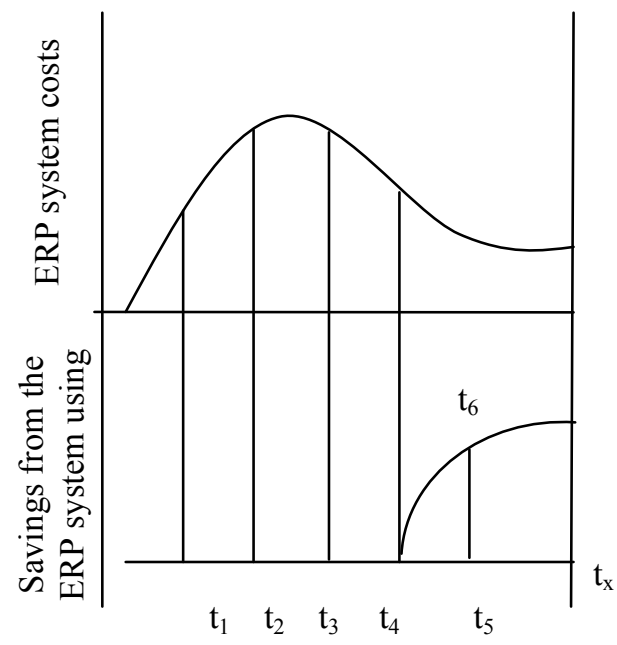

Fig. 3. Evaluation of the integral curves

Savings from the ERP system using $\left(S_{I M S}\right)$ is defined as:

$$
S_{I M S}=E_{I M S}-Z_{I M S} \rightarrow \max [\{Y\},\{V\},\{U\}]
$$

here $E_{I M S}$ - organization' integrated economic effect by business processes automating (and as a result increasing of relative average productivity of ERP system users);

$Z_{I M S}$ - integral costs for development of MIS;

$\{Y\}$ - set of management functions to be automated;

$\{V\}$ - business processes to be automated; consider a lot of social, psychological, legal, ergonomic, organizational, managerial, organizational, technical and economic factors, as well as ERP system indirect impact on the labour through human control; difficulty of allocating the economic effect of the ERP system from the common effect associated with the improvement of management of the organization.

Saving from the application of ERP system is largely determined by the cost of management reforming, by the cost of development, implementation and fine-tuning of the IS software, and operating costs. The problem of creating an effective and modernization of the existing ERP system remains relevant in the design and operation of the system and could be achieved with the optimal balance of cost saving from system development and time parameters defining the ERP system. The dependence of these characteristics can see through the comparison of the organization' savings from the processes automation and various stages costs of ERP system development, and also through the evaluation of the integral curves (Fig. 3).

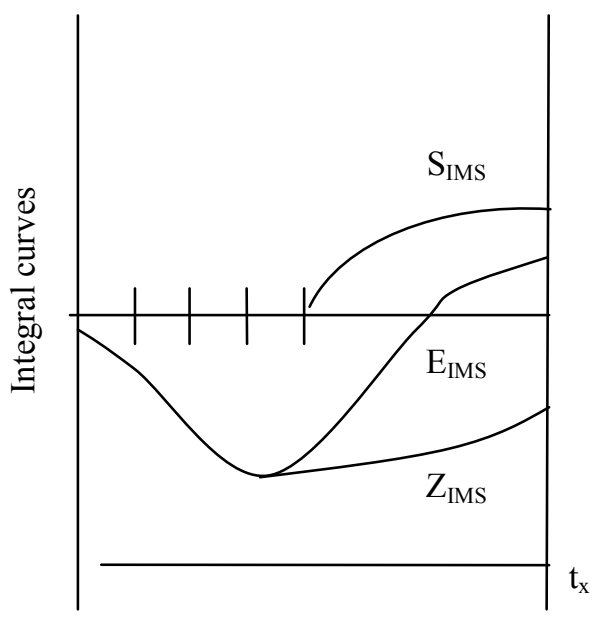

$\{U\}$ - information system's architecture and structure (business architecture, hardware and technical architecture and information system's platform).

As the time intervals:

$t_{l}$ - start of the system and technical design;

$t_{2}$ - start of the detailed design;

$t_{3}$ - start of trial operation;

$t_{4}$ - beginning of commercial operation;

$t_{5}$ - time of full system's development;

$t_{6}$ - system payback time;

$t_{x}$ - standard period of the system life cycle. 
Integral costs for development of MIS shows equation (2):

$$
Z_{I M S}=\frac{\left(Z_{S W}+Z_{B P R}+Z_{T P}+Z_{H W}+Z_{W}\right)}{t k}+Z_{A}+Z_{B C}+Z_{F C}
$$

here $Z_{S W}$ - the development costs of the software (including research and development) and for purchase of licensed software;

$Z_{B P R}$ - costs associated with the set of measures to business processes re-engineering and the development of optimal business architecture in the organization;

$Z_{T P}$ - costs associated with the development of systemtechnical and working projects;

$Z_{H W}$ - capital investment in data transmission systems and ERP system hardware;

$Z_{W}$ - costs associated with the start-up operations and installation components;

$Z_{A}$ - depreciation costs;

$Z_{B C}$ - current annual operating costs (basic and additional cost with deductions), maintenance of equipment, rental costs for computer tools, and other expenses;

$Z_{F C}$ - current annual costs on the ERP system development.

In general, the mean relative productivity of users using ERP system $(P)$ is:

$$
P=\sum_{i} P_{i}
$$

here $P_{i}$-evaluation parameters of performance increase in $\%$ for following functional units:

$P_{1}-$ performance from the business processes reengineering and optimal integrated document management (reduction of losses, information errors, control of information flow etc.) in ERP system development;

$P_{2}$ - performance obtained by automating previously not automated business processes (also acceleration of existing business processes), time reduction of information processing;

$i$ - the number of performance's parameters.

Annual economic effect $(E)$ from the ERP system using by the personnel can be calculated using equation (4):

$$
E=\frac{(P-100) * N * I * C}{100}
$$

here $P$ - t the average relative productivity of users using ERP system;

$N$ - the average number of workers using an automated workplace;
$I$ - weighted average number of shifts (1-2);

$C$ - the average salary's stimulation index per employee in the system per year.

The MIS payback period equal to:

$$
T=\frac{Z_{Q}}{E}=\frac{\left(Z_{S W}+Z_{B P R}+Z_{T P}+Z_{H W}+Z_{W}\right)}{E}
$$

here $Z_{q}$ - the total cost of ERP system development.

So, MIS efficiency ratio is equals to:

$$
e=\frac{1}{T}
$$

In applying the above mentioned methodology in practice authors faced with the fact that there is a system of constraints to improve enterprise management. The main ones are:

- Lack of information and not operational using of its in management;

- Lack of integration of business processes;

- Lack of elaboration of the enterprise management basics, i.e. inappropriate content of the existing management functions to the new work conditions;

- Lack of regimentation of the management goals and information technology management processes.

There are different ways to assess the effectiveness of ERP system implementation. But usually the typical results are follows:

- $15-25 \%$ increase of productivity;

- $10-20 \%$ reduction of inventory;

- $20-50 \%$ reduction of orders' fulfilment.

\section{CONCLUSIONS}

To improve the technical and economic performance characteristics, and as a result ERP system operation, authors suggest the following management solutions:

- if the number of ERP system users increase, then the main role plays the architecture of computer network, because capacity of the network itself can become a bottleneck;

- continuously improving of personnel professionalism, especially for the personnel responsible for the input and control of system data;

- develop software compatible with the ERP system, especially for the automation of various solutions for manufacturing; 
- develop and enhance integration of information modules, increase flexibility and efficiency of the ERP system.

To build an effective system, there are three main conditions: it must be productive; it must be followed up, and it must have big time of real life, that is, the life cycle of the ERP system.

These conditions are interdependent and may be achieved by following activities:

- development of sustainable economic and information models of enterprise;

- reengineering of business processes and at the same time improving of the management structure and techniques;

- optimal use of resources during operation.

In general, the benefits of ERP system are follows:

- increase the speed of information exchange;

- reduce the number of errors in accounting;

- reduce the amount of non-productive, "paper" work;

- combine previously fragmented pieces of information.

\section{ACKNOWLEDGMENT}

The authors acknowledges the financial support provided by the ERAF project "Riga Technical University international cooperation, projects and capacity development in science and technology Nr. 2DP/2.1.1.2.0/10/APIA/VIAA/003" for this research.

\section{REFERENCES}

[1] Ahitur, N., S. Neumann, and M. Zviran. (2002). A System Development Methodology for ERP Systems. Journal of Computer Information Systems, Spring. 56-67.

[2] Anne, P. and G. Shanks. (2002). A Model of ERP Project Implementation. Journal of Information Technology, 15:4, 289-303.

[3] Bingi, P., Sharma, M.K., Godla, J.K. (1999). Critical issues affecting an ERP implementation. Information Systems Management 16 (3), 7-14.

[4] Burns, M. (2003). "Fifth annual accounting and ERP survey", Retrieved April 29, 2004, from http://www.camagazine.com/index.cfm/ci_id/16455/la_id/1.htm .

[5] Chen, I. (2001). Planning for ERP systems: Analysis and future trend. Business ProcessManagement Journal, 7(5), 374-386.

[6] Chiara, F. (2001). Predicting the Implementation Effort of ERP Projects: Empirical Evidence on SAP/R3. Journal of Information Technology, $16: 1,33-48$

[7] Davenport, T. H. (1998). Putting the enterprise into the enterprise system. Harvard Business Review, 76(4), 121-131.

[8] Davenport, T. H. (2000). Mission critical: Realizing the promise of enterprise systems. Boston, MA: Harvard Business School Press.

[9] Griffith, T.L., Zammuto, R.F., Aiman-Smith, L. (1999). Why new technologies fail? Industrial Management 41 (3), 29-34.

[10] Grossman, T., \& Walsh, J. (2004). Avoiding the pitfalls of ERP system implementation. Information Systems Management, 21(2), 38-42.

[11] Huang, S.M., Irene, S.Y. and Hung, Y.C. (2001). Planning Enterprise Resources by Use of a Reengineering Approach to Build a Global
Logistics Management System. Industrial Management \& Data Systems, 101:9, 483-491.

[12] Huang, K.K. and Y.G. Kim. (2002). The Critical Success Factors for ERP Implementation: An Organizational Fit Perspective. Information \& Management, 40:1, 25-40.

[13] Jessup L., Valacich J. (2006). Information Systems Today: Why IS Matters. 2 ed. Pearson Education, Inc.

[14] Kim, Y., Lee, Z., \& Gosain, S. (2005). Impediments to successful ERP implementation process. Business Process Management Journal, 11(2), $158-170$.

[15] Klaus, H., Roseman, M., Gable, G. (2000). What is Enterprise Resource Planning?, Information Systems Frontiers, vol.2, no.2., pp.141-162.

[16] Krumbholz, M., J. Galliers, N. Coulianos, and N.A.M. Maiden. (2000). Implementing Enterprise Resource Planning Packages in Different Corporate and National Cultures. Journal of Information Technology, 15:4, pp. 267- 269 .

[17] Li H, Li L. (2000). Integrating systems concepts into manufacturing information systems. Systems Research and Behavioral Science 17: 135-147.

[18] Markus, M. L., Axline, S., Petrie, D. \& Tanis, C. (2000). Learning from adopters' experiences with ERP: Problems encountered and success achieved. Journal of Information Technology, 15(4), 245-266.

[19] Mertins K, Jochem R. (2005). Architectures, methods and tools for enterprise engineering. International Journal of Production Economics.

[20] Motwani, J., D. Mirchandani, M. Madan, and A. Gunasekaran. (2002). Successfiil Implementation of ERP Projects: 37. Evidence from Two Case Studies. International Journal of Production and Economics, 75:1, 83-96.

[21] O'Leary, D. (2000). Enterprise Resource Planning systems. Cambridge, UK: Cambridge University Press.

[22] Porter, M.E. (1985). Competitive Advantage: Creating and Sustaining Superior Performance. New York: Free Press.

[23] Porter, M.E., Millar V. (1985). How Information Gives You Competitive Advantage. Harvard Business Review 63 (4): 149-161.

[24] Rajagopal P. (2002). An innovation-diffusion view of implementation of enterprise resource planning (ERP) systems and development of research model. Information \& Management 40. 87-114pp.

[25] Ross, J.W., Vitale, M.R. (2000). The ERP revolution: surviving vs thriving. Information System Frontiers. 2 (2), 233-241.

[26] Scheer, A.W. and H. Frank. (2000). Enterprise Resource Planning: Making ERP a Success. Communications of the ACM, 43:4, 57-61.

[27] Soh, C., Kien, S. S., \& Tay-Yap, J. (2000). Cultural fits and misfits--Is ERP a universal solution? Communications of the ACM, 43(4), 47-51.

[28] Umble, E.J., \& Umble, M.M. (2002). Avoiding ERP implementation failure. IndustrialManagement, January / February, 25-33.

[29] Volkoff, O., Strong, D. M., \& Elmes, M. (2005). Understanding enterprise systems-enabled integration. European Journal of Information Systems, 14, 110-120.

\section{Creative Commons Attribution License 4.0 (Attribution 4.0 International, CC BY 4.0)}

This article is published under the terms of the Creative Commons Attribution License 4.0 https://creativecommons.org/licenses/by/4.0/deed.en US 